\title{
REINFORCEMENT IDENTITY OF TOURISM VILLAGE AT DUSUN WANGUN -BANDUNG
}

\author{
Titi Indahyani ${ }^{1 *}$, Yunida Sofiana ${ }^{1}$, Ari Yuniarso ${ }^{1}$ \\ ${ }^{1}$ Bina Nusantara University \\ tindahyani@binus.edu
}

\begin{abstract}
As an effort to support the tourism promotion of Dusun Wangun tourism village, it is crucial to develop a souvenir design strategy for the village including product display arrangement. The unique souvenirs play a role in strengthening the identity of tourism village that potentially attract more tourists to visit the village and purchase the unique souvenirs. It is expected that with the purchase of unique souvenir products that produced by local people and inspired by coffee, as one of the superior products of the village, might potentially improve the welfare of the local community and support the sustainability of coffee plantations. The method used in this research is literature data review to gather various information of local souvenirs and design, field work survey and observation, interview, swe art application, workshop training analysis, prototyping, design implementation and exhibition as part of product testing and evaluation. The output of this community development is the improvement of skill and knowledge of local women community. In addition, there are also a video documentation of the training processes and a "story telling" of product catalogue that contains the souvenir design and production process documentation for further education and product promotion.
\end{abstract}

Keywords: Souvenir, identity, tourism village, local community, sew art

\section{INTRODUCTION}

As tourism village, dusun or kampong Wangun in Pasirmulya village that located in South Bandung regency in West Java has the potential to support tourism program through the development of unique souvenirs including its display arrangement. In Wangun, most of the local community work as coffee farmers. As one of main superior product from Pasirmulya, coffee beans that produced from this region has already received a prestigious international recognition award. This recognition is potential to be an economic driven for coffee farmers and local people in Pasirmulya for their future benefit. Therefore, it is critical to develop additional products to support the sustainability of local coffee through various merchandise and handicraft product items (souvenirs), including packaging design that could benefit the business and tourism program, and also improve the welfare of local communities.

To support tourism promotion in Wangun, it is very important to develop a souvenir design strategy. The design can be inspired from coffee and natural environment as local unique characteristics that strengthens the value-added of tourism village identity and potentially attract tourists to purchase unique goods. According to Suhartanto (2016) tourist satisfaction with souvenir shopping experience is an important determinant of tourist perception on destination image and tourist loyalty toward a destination. It is expected that with the increasing purchase of souvenir products as one of the village's superior products in future, might improve the welfare of local community. Through the increased purchases of coffee products as part of souvenirs and collection of new souvenir products that produced by the local community in supporting the promotion of tourism program, potentially has positive advantage for the sustainability of coffee plantations. The general objective of this community partnership program is to apply knowledge of design, production and packaging of unique tourism souvenirs that applied hand-sewing technique for local communities in Dusun Wangun. The program also implement design knowledge for display booth as supporting furniture. It is expected that through the understanding of souvenirs and overall design process 
and implementation can help rural women, especially PKK (family welfare development) in producing souvenir for tourism village in Dusun Wangun. Souvenirs produced through the implementation of four basic hand sewing techniques of fabric applications on bags, totte bag, simple wallet, shoulder bags, packaging for coffee products, and various pin to meet the target market needs. There were also simple basic skills for branding, packaging and product display to support sales, marketing and promotion strategy for this empowerment program.

\section{METHOD}

The method used data collecting literature of various types of souvenirs, including tourism village, opportunities and target markets. Furthermore, a field review conducted to document local characteristics ideas that potentially used as souvenir design inspiration. As additional supported data, observation and interviews also applied in this program. For further program implementation, there were several training materials provided for workshop in several stages. The workshop activities, then, evaluated before and after the workshop for training material improvement. To get more feedbacks from public, an exhibition conducted to get input from targeted market.

\section{RESULT AND DISCUSSION}

Rural area is an area that has main activities in agriculture, including natural resource management, with residential area arrangement, government services, social services, and economic activity (Yoltuwu, J.M, 2015). As one of nature tourism, tourism village can be developed by utilizing local potential. According to Hawaniar and Suprihardjo (2013), tourism village is a form of integration between accommodation, attractions, and supporting facilities that are presented in a structure of community life that embed with prevailing procedures and traditions. To develop regional tourism through local community knowledge and skills improvement, this women empowerment program that conducted in Dusun Wangun also aims to increase environment, art and culture awareness. The program is also expected to improve people's welfare through job opportunities.

\section{The Potential Aspects of Dusun Wangun}

There are four potential aspects of Pasirmulya village that support tourism village program in Dusun Wangun. First, the potential of agricultural or plantation products, especially coffee beans, sorghum and soybeans. Coffee bean is one of superior product for Pasirmulya, which has been internationally awarded for the first prize of the American Association of Coffee Specialization Association (SCAA) Expo in 2016 in Atlanta, Georgia, USA. The natural daily life of coffee farmers, then, potential to support the tourism activities through local home stay program as part of tourist facilities. Second, there is potential for natural beauty of landscape, such as Mount Puntang and pine forests which are one of the tourist destinations in Pasirmulya village. This natural beauty can be explored in inspiring various souvenirs. Third, the potential of micro and small businesses and talented women empowerment resources. As part of women community in Dusun Wangun, Kfamily walfare development that focused on the family welfare education, has already a group of member that has basic sewing skills. These women community potentially further empowered and developed in producing creative and commercial souvenir products for tourism village while increasing their income. Fourth, Pasirmulya also producing waste materials through its coffee beans waste materials and Micro Small Medium Enterprises activities such as, leather and textiles from shoes and garment production.

The waste materials potential to be developed as substitute materials in producing souvenirs while also support the use of friendly environment materials and sustainable development programs. All of the above potential aspects shows that as tourism village, Pasirmulya has potential factors for unique souvenirs to be explored and commercialized to support the tourism programs, attract more tourists and increase the income of local society.

Participant's partners in Dusun Wangun are women community, who have basic sewing skills. As an effort to support the program in producing creative and various products with good quality in meeting the target market and opportunities. these women with basic sewing skills still require special 
training in terms of design development and sewing application techniques that use patchwork or fabric waste materials.

\section{The Problems faced by local community}

There are two main problems that faced by local community in Pasirmulya tourism village. First, lack of local souvenir products that support tourism promotion while increasing community income. There is a need to provide unique local souvenirs that integrate local community skills limitation. According to existing capabilities and to optimally utilize local materials, there is also a need to develop souvenirs that used local materials, including waste materials. Second, lack of local community knowledge for product display, marketing and promotion that could able to attract tourists and support tourism village program. Other challenges are including human resources (HR), materials and financing:

Human Resources

- Program Partners (farmer and PKK community) or workshop participants, have basic skills in hand sewing technique

- Workshop Participants only have available schedule after 9 am or after their farming activities

- Participants have to daily take care of their children (generally at toddlers and elementary school age)

\section{Materials:}

- Materials used for hand sewing application can use fabric waste material from workshop participant's own local surrounding

- Other various basic fabric materials can be simply obtained from with an online order system

\section{Financing}

Partners, as potential creative workers do not have sufficient funds to produce souvenirs products by their independent funds

Generally, partners faced the problems in improving the welfare of local community in tourism village destination in Dusun Wangun, Pasirmulya Village that need unique sustainable souvenir products through effective marketing and promotion strategy that can attract more tourists.

\section{Objectives, Targets, Time Frame}

Participants of this program is member of rural women community: farmer and family welfare development (PKK). The purpose of this omen empowerment program is to provide training in hand sewing as souvenirs to 15 women members of both community. It is expected that the training participants will get additional skills in the production of unique souvenirs for tourism village by following the instructions and guidance during the training activities. Also, participants expected to share and explore their new knowledge to their surrounding community for future impact and sustainability of products. This program is expected to provide awareness for the people of Dusun Wangun and its surroundings about the importance of knowledge and skills related to design strategies in developing and supporting superior products, such as Puntang coffee which has the potential to improve the welfare of rural communities.

This program is an intensive training and training in hand sewing technique into a number of souvenir products. The training also includes the introduction of creative economy and creative industries that can improve the economic value of a product, and provide several alternative products based on local ingredients and local waste materials. It is expected that design and products that produced by the community in Dusun Wangun have the potential to support tourism promotion and increase community income.

The outputs include training materials, sketches and design patterns for typical village souvenir products, sample / product prototypes and sketches of booth designs and exhibitions. Further outputs as follows:

- Support tourism promotion in the Tourism Village through the procurement of locally produced souvenir products

- Preserve local culture 
- Explore local values as a souvenir inspiration: coffee, natural environment, local culture that could strengthening the identity of tourism village

- Support the sustainability of coffee plantations and local MSMEs through the purchase of local materials and production

- Improve community welfare, throughtraining and mentoring skills, product sales and marketing, and attract more tourists

\section{Program Planning}

Hand Sewing workshop/training programs are part of a long-term program:

"One Stop Shopping Culture Market and Learning House" that has main targets:

- Improving tourism village identity and the welfare of local communities who support tourism village program through:

- mobile shopping market (flexible display booth)

- mobile workshop and product demo spot (flexible learning area)

- Souvenir shopping center

- Unique local food and beverage center

- Art and Culture Market (to introduce local culture)

- Learning Center (creative products learning for tourists and local community)

Program Implementation are divided into four steps:

1. Participants and duration of training

- The program is implemented in three trips with a duration of time approximately 3-4 hours each trip

- Participants are women community

2. Training Preparation

- Socialize the implementation of training to community leaders in Pasirmulya Village

- Prepare training materials in accordance with existing human resources

3. Evaluation

- Conduct evaluations before and after training to determine the impact of training and to review training materials

4. Exhibition

- Conduct marketing preparations through the "community product brands" in collaboration with visual communication designer

- Support product display arrangement, including sales and marketing strategy

- Collect market data for product repairs

\section{CONCLUSION}

This empowerment program support the development of basic hand-sewing skills gained from training into various unique souvenirs for Dusun Wangun tourism village. The program also encouraged workshop's participants (partners) to become temporary tutors for other participants during the workshop. It is expected that with this transfer knowledge activities, Dusun Wangun has their own local tutors to assist other potential local participants. According to Zapata (2011) traditional community based tourism that created and fully funded by external organisations, demonstrated longer life expectancy, faster growth, and more positive impacts on the local economy. In addition, this program opened the collaboration opportunity across multidiscipline for product sustainability in relation to overall design, market and promotion. Thus, in future, this empowerment program potential to support product sustainability that has positive impact for tourism village program in Dusun Wangun and increase the welfare of society while enhancing the tourism village identity. 


\section{REFERENCES}

Cohen, S.A. et al . (2013) Consumer behaviour in Tourism : Concepts, Influences and opportunities. Current issues in Tourism, 17(10), 872-909.

Hawaniar, M \& Suprihardjo, R. (2013). Kriteria Pengembangan Desa Slopeng sebagai Desa Wisata di Kabupaten Sumenep. Jurnal Teknik Pomits Vol. 2, No. 3, (2013) ISSN: 2337-3539 (2301-9271 Print). http://download.portalgaruda.org/article.php?article=133581\&val=4186

Nuryanti, Wiendu (1993). Concept, Perspective and Challenges, Part of InternationalConference Report on Culture Tourism. Yogyakarta, Gadjah Mada University Press

Suhartanto. D. (2016) Tourist Satisfaction with souvenir shopping : evidence from Indonesian Domestic Tourists. Current issues in Tourism, 21(6), 663-669.

Yoltuwu, J.M. (2015). Sosialisasi Pelaksanaan UU No.6 Tahun 2014 Tentang Desa. Retrieved from https://www.kemenkopmk.go.id/sites/default/files/field/file_pendukung/Kewenangan\%20Tup oksi\%20Ditjen\%20PKP_2015.pdf

Zapata, M.J. et al. (2011) Can Community-based tourism contribute to development and poverty alleviation? Lesson from Nicaragua, Current Issues in Tourism, 14(8), 725-749. 